\title{
Variability in the response of the rabbit uterus to progesterone as influenced by prolactin
}

\author{
J. C. Daniel, Jr, S. C. Juneja*, S. P. Taylor*, P. B. Lonergan*, \\ P. K. Sullivan* and B. S. Chilton $\dagger$
}

College of Sciences, Education Building, RM 218, Old Dominion University, Norfolk, VA 23529, U.S.A.; and *Bology Department, Old Dominion University, Norfolk, VA 23529, U.S.A.; and

$\doteqdot$ Department of Cell Biology \& Anatomy, Texas Tech University Health Sciences Center, Lubbock, TX 79430, U.S.A.

\begin{abstract}
Summary. Ovariectomized rabbits from different breeders were treated at different times of the year with prolactin alone or with progesterone and the production of uteroglobin by the uterus was studied. There were seasonal, strain and dose variables in the uterine response to prolactin and progesterone. Treatment with prolactin (at $1 \mathrm{mg} /$ day) plus progesterone generally induced higher levels of uteroglobin production than did treatment with progesterone alone. The differences were greatest in the winter for Tennessee animals and in the spring for animals from the New Mexico and North Carolina colonies.

Ovariectomy produced a decrease $(P<0.01)$ in the concentration of cytosolic oestrogen and progesterone receptors, and prolactin treatment restored the concentration to oestrous control values. However, there were no seasonally dependent changes in the concentration of the receptors for any of the treatment groups.

Increased doses of prolactin ( $2 \mathrm{mg} /$ day) induced high levels of uteroglobin production and new proteins to appear in uterine secretions of long-term ovariectomized rabbits but much lower levels $(10-11 \%)$ when given to pregnant does. Additional ovulations were also noted plus adverse effects on the embryos.
\end{abstract}

Keywords: prolactin; rabbit uterus; uteroglobin; progesterone; seasonal variability

\section{Introduction}

Prolactin treatment causes an increase in the concentration of cytosolic oestrogen and progesterone receptors in the uteri of rabbits that have been ovariectomized for 12 weeks or longer, and when combined with progesterone treatment the resulting uteroglobin production in these animals significantly exceeds that produced by progesterone alone (Daniel et al., 1984). Endometrial proliferation and gland formation also results from the synergistic interplay of prolactin and progesterone (Chilton \& Daniel, 1985). In extending the original work, some variability was encountered which appeared to be related to season of the year.

Steroid hormone receptor activity in homoeotherms is influenced by season. Spelsberg et al. (1983) present evidence for seasonal rhythms in nuclear binding of the chick progesterone receptor. Hughes et al. (1976) reported seasonal variation in tissue concentration of oestrogen receptors from several mammalian species and Barbanel \& Assenmacher (1984) reported diurnal variations in oestrogen receptor concentrations in various target organs of prepubertal rats. Stern \& Vaughan (1987) described seasonal changes in the affinity $\left(K_{\mathrm{a}}\right)$ of the oestrogen receptor for oestradiol in rabbit uteri; this phenomenon accompanies seasonally dependent differences in fecundity in this 
species. Because prolactin may augment the effect of progesterone on uterine protein secretion by modulating some aspect of the steroid hormone receptor system, we initiated a study to determine the effects of season and other variables on this dynamic interaction.

\section{Materials and Methods}

Animal treatment. New Zealand White rabbits (3.5 $4.5 \mathrm{~kg} ; 6$ months old) were obtained from three different breeders located in Tennessee, North Carolina and New Mexico, respectively, and 130 animals were used over a 2-year period. Rabbits were anaesthetized with ketamine hydrochloride (Ketaset: Bristol Laboratories, Syracuse, NY, U.S.A.) and xylazine (Rompun-Haver-Lockart: Shawnee, KS, U.S.A.), bilaterally ovariectomized, and maintained for at least 12 weeks before experimentation. Ovariectomies were timed so that the 12-week post-surgical period was completed and treatment initiated in the winter (December-March) for one group of animals from each of the three breeders, and in the spring (April-June) for the second group of animals.

The first experiment was designed to define the effects of season and strain on the uterine response to progesterone as modulated by prolactin. Five experimental groups were identified according to state of origin and season of the year: Tennessee-spring, North Carolina-spring and -winter and New Mexico-spring and -winter. Data from Daniel et al. (1984) were used to provide a sixth group designated Tennessee-winter. Each group was divided into 4 treatment subgroups of 4-6 animals each. Treatment regimens were as follows: (1) 5 daily, subcutaneous injections of $1 \mathrm{mg}$ ovine prolactin (Sigma Chemical Company, St Louis, MO, U.S.A.) in phosphate-buffered saline (PBS); (2) 4 daily injections of progesterone (3 mg/kg: Sigma) in corn oil; (3) 5 daily injections of prolactin followed by 4 daily injections of progesterone; (4) 5 daily injections of PBS followed by 4 daily injections of corn oil (controls). Other controls included oestrous and 5-day pregnant rabbits.

Uterine fluid collection and analysis. At $6 \mathrm{~h}$ after the last injection, rabbits were killed by cervical dislocation (Daniel \& Boyce, 1978). The abdomen was opened via a mid-ventral incision and the uterus excised, trimmed of fat and blotted with sterile gauze. Each animal was carefully checked for any ovarian remnant that might remain from the surgery. If any remnant was found, the animal was eliminated from the study. Each uterine horn was flushed with $5 \mathrm{ml}$ PBS.

Flushings were transferred to dialysis tubing (Spectra/Por 3: American Scientific Products; McGraw Park, IL, U.S.A.), dialysed against two changes of distilled water at $4^{\circ} \mathrm{C}$ for $24 \mathrm{~h}$, concentrated with carboxmethyl cellulose powder (Aquacide: Behring Diagnostics; La Jolla, CA, U.S.A.) and lyophilized to dryness. The lyophilized powder was dissolved in specific volumes of PBS and the total protein concentration was determined by the procedure of Lowry et al. (1951).

The uteroglobin concentration was measured by single immunodiffusion against a goat anti-uteroglobin as described by Daniel et al. (1984) modified from Oudin (1952) and Crowle (1973). Essentially, the procedure consists of introducing the sample for which the uteroglobin content is to be determined to the surface of a $0.5 \%$ agarose gel, containing the antiserum, which had been preformed in a small Pyrex glass tube (3-mm internal diameter $\times 5 \mathrm{~cm}$ length). Once standardized, the speed with which a precipitation line between the antigen and antibody moves through the gel is constant according to the concentration of uteroglobin. Uteroglobin levels are expressed as \% $(\mu \mathrm{g}$ uteroglobin $/ \mu \mathrm{g}$ total protein). For the antiserum used in these experiments, the intra-assay variation (CV) was $3.5 \%$ and the inter-assay variation was $11 \%$.

Protein separation by electrophoresis. Representative samples were analysed by polyacrylamide gel electrophoresis using $8 \%$ resolving gel on a Bio-Rad system with the Tris buffers described by Furlong et al. (1973). Samples consisted of $200 \mu \mathrm{g}$ protein, except when the total protein available was so low that the complete sample was used. Gels were stained in $10 \%$ acetic acid with $0.1 \%$ amido black and destained with Bio-Rad destainer and $10 \%$ acetic acid. All reagents used for electrophoresis were purchased from Sigma Chemical Company (St Louis, MO, U.S.A.)

Tissue preparation for receptor assays. Uterine endometrium was scraped from underlying myometrium, weighed and homogenized $(100 \mathrm{mg} / \mathrm{ml})$ as previously described (Daniel et al., 1984; Chilton \& Daniel, 1987). Aliquants ( $100 \mu \mathrm{l})$ were reserved for DNA assay according to the method of Burton (1956) using calf thymus DNA as the standard. Cytosolic fractions and extracted nuclear pellets were prepared as previously described (Daniel et al., 1984), and assayed for total oestrogen and progesterone receptor concentrations.

Receptor assays. The concentrations of total oestrogen and progesterone receptor were determined by Scatchard (1949) analysis of specific binding data using the assay procedures previously described by Chilton \& Daniel (1987). Briefly, aliquants of cytosol and nuclear extracts were incubated with increasing concentrations (0.5-20.0 nM) of $\left[{ }^{3} \mathrm{H}\right]$ oestradiol or $\left[{ }^{3} \mathrm{H}\right] \mathrm{R} 5020$ (total binding). Parallel samples were incubated with 100 -fold excess of diethylstilboestrol (DES) or radioinert R5020 for evaluation of non-specific binding. Samples were incubated at $30^{\circ} \mathrm{C}$ for $3 \mathrm{~h}$ to measure total oestrogen receptor and at $4^{\circ} \mathrm{C}$ for $18-20 \mathrm{~h}$ to measure total progesterone receptor. A single saturating dose assay was used when tissue samples were very small (Chilton \& Daniel, 1987). For this assay, samples were incubated with a final concentration of $20.0 \mathrm{nM}-\left[^{3} \mathrm{H}\right]$ oestradiol $\pm 2.0 \mu \mathrm{M}$-DES or $20.0 \mathrm{nM}-\left[{ }^{3} \mathrm{H}\right] \mathrm{R} 5020 \pm 2.0 \mu \mathrm{M}-$ radioinert $\mathrm{R} 5020$. Seasonal variability in the concentrations of cytosolic oestrogen and progesterone receptors was evaluated using the unpaired Student's $t$ test. 
Effects of different dosages of prolactin. Uteroglobin and steroid hormone receptor concentrations from the winter treatment groups of animals (from all three geographic locations) were pooled according to subgroup designation, i.e. those treated with prolactin $(1 \mathrm{mg})$, with progesterone $(3 \mathrm{mg} / \mathrm{kg})$, or prolactin plus progesterone. These results were compared with those from animals, from all three geographical locations, that received $0.5 \mathrm{mg}$ prolactin alone, or in combination with progesterone, and with New Mexico rabbits in the springtime and North Carolina rabbits in the winter receiving $2 \mathrm{mg}$ prolactin alone or with progesterone.

Effects of prolactin on pregnancy. To test the effects of high dosages of prolactin on early pregnancy, 4 rabbits were mated on the morning of Day 0 and injected with $2 \mathrm{mg}$ prolactin in PBS on the afternoon of Days 2,3 and 4 post coitum. Four control does were sham injected (PBS alone) according to the same schedule. All animals were killed on Day 5, and the uteri were flushed as described above. The corpora lutea and mature follicles were counted and measured. The number of embryos recovered in the uterine flushings was compared to the number of corpora lutea and the embryos were examined for normal size, shape and conformation. The concentration of uteroglobin in the uterine flushings was determined as described above.

\section{Results}

\section{Influence of season and strain on uteroglobin production}

Seasonally dependent differences in the uterine secretory response to prolactin + progesterone by different strains of New Zealand white rabbits are illustrated in Fig. 1. Prolactin + progesterone treatment elicited the greatest concentration of uteroglobin, i.e. $62 \cdot 3 \pm 6 \cdot 2 \%$ of the total uterine protein, in the animals from Tennessee during the winter. The concentration of uteroglobin from these animals was 5-fold greater than the response of the same strain during the spring, and 2-fold greater than the wintertime response of animals from New Mexico. The concentration of uteroglobin from the New Mexico animals was approximately 2-fold greater than that of North Carolina animals during the spring months. Animals from New Mexico and North Carolina secreted equivalent mean concentrations of uteroglobin when treated during the winter; however, as shown by the large standard errors, the response of animals of both strains was highly variable during this season. The treatment of all ovariectomized animals with prolactin alone, or shaminjected, resulted in uterine secretions devoid of uteroglobin.

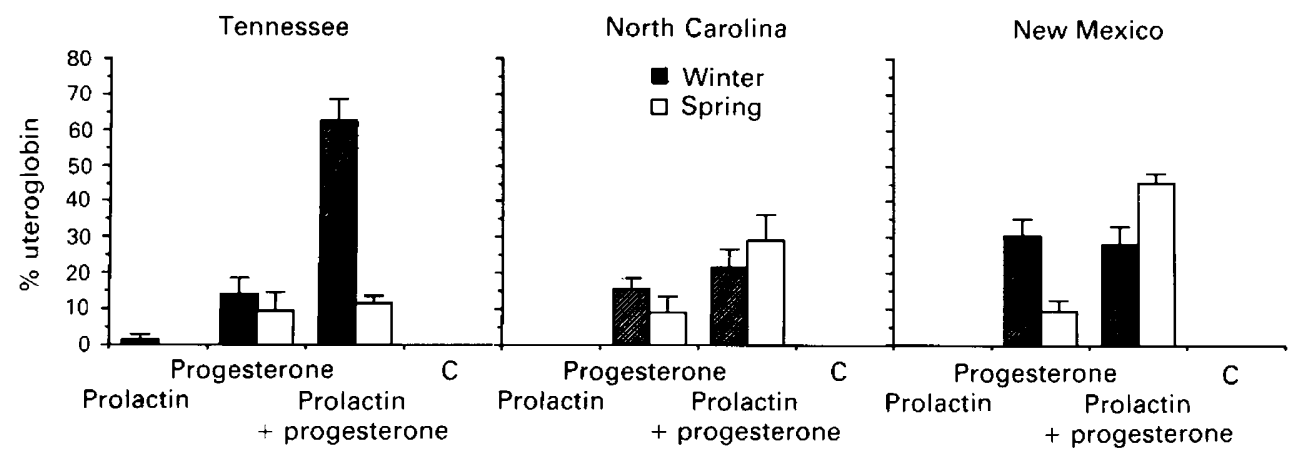

Fig. 1. Seasonally dependent differences in the uterine secretory response to the various treatment regimens. Values are mean \pm s.e.m. for 130 does $(4-8 /$ treatment/season). Controls (C) were long-term ovariectomized does.

Seasonal variability was also noted in the secretory response of animals treated with progesterone alone, although it was consistently low $(\sim 9 \%)$ in the spring in all the strains. A uteroglobin concentration of $30 \cdot 6 \pm 4.5 \%$ was determined for animals from New Mexico during the winter. This value represents a 3-fold increase over the $9.8 \pm 3.0$ value for the same strain of animals during spring. However, the value of uteroglobin for New Mexico and North Carolina animals 
during the spring is not significantly different from the value of $14.3 \pm 4.6 \%$ uteroglobin for Tennessee animals during the winter. Values for North Carolina animals were increased $71 \%$ during the winter; and the lowest value of $9 \cdot 2 \pm 4 \cdot 6 \%$ uteroglobin was recorded for these animals during the spring.

\section{Prolactin dependence of uteroglobin secretion}

Table 1 illustrates the effects of various concentrations of prolactin on uteroglobin secretion when the concentration of progesterone $(3 \mathrm{mg} / \mathrm{kg}$ body weight) remained constant. The treatment of New Mexico animals with $0.5 \mathrm{mg}$ prolactin daily failed to increase the concentration of uteroglobin above control values (progesterone alone). The treatment of rabbits with $1.0 \mathrm{mg}$ prolactin daily resulted in a 2 -fold increase in the uteroglobin content. Moreover, the treatment of New Mexico rabbits in the spring with $2.0 \mathrm{mg}$ prolactin daily resulted in a 3-fold increase in the uteroglobin content, while the total uterine protein content was unchanged compared to control values (progesterone alone). The $2 \mathrm{mg}$ dose of prolactin given to North Carolina rabbits in the winter had the same effect on uteroglobin production as did a $1 \mathrm{mg}$ dose $(15.4 \pm 5.9 \%$ for $2 \mathrm{mg}, 21.8 \pm 5 \%$ for $1 \mathrm{mg}$ ). The administration of prolactin alone, at the 1 and $2 \mathrm{mg}$ doses, failed to induce any detectable uteroglobin production.

Table 1. Uteroglobin production in response to increasing concentrations of prolactin + progesterone $(3 \mathrm{mg} / \mathrm{kg} /$ day $)$

\begin{tabular}{lcc}
\hline Prolactin treatment & $\begin{array}{c}\text { Total uterine protein } \\
\text { (mg protein/uterus) }\end{array}$ & $\begin{array}{c}\% \text { Uteroglobin } \\
(\mu \mathrm{g} / \mu \mathrm{g} \text { protein) }\end{array}$ \\
\hline $0.0 \mathrm{mg} /$ day + progesterone & $2.36 \pm 0.56$ & $18.8 \pm 4.2$ \\
$0.5 \mathrm{mg} /$ day + progesterone & $2.07 \pm 0.62$ & $17.9 \pm 2.9$ \\
$1.0 \mathrm{mg} /$ day + progesterone & $2.41 \pm 0.40$ & $37.8 \pm 4.3$ \\
$2.0 \mathrm{mg} /$ day + progesterone & $2.85 \pm 0.38$ & $59.5 \pm 10.3$ \\
$1.0 \mathrm{mg} /$ day (controls) & $0.15 \pm 0.05$ & 0 \\
$2.0 \mathrm{mg} /$ day (controls) & $0.26 \pm 0.04$ & 0 \\
\hline
\end{tabular}

Treatment with prolactin alone, and sham injection, produced negligible uteroglobin in New Mexico does (Fig. 2). Uteroglobin could be identified in the flushings from animals treated with progesterone or prolactin plus progesterone, but the relative concentration was $1 \cdot 7$-fold greater in the animals treated with $2 \mathrm{mg}$ prolactin than with $1 \mathrm{mg}$ as determined by densitometry. These results agree with values reported in Table 1 . The progesterone alone sample had a very low concentration of uteroglobin and a distinct albumin component but very little prealbumin. The higher uteroglobin level in the $2 \mathrm{mg}$ prolactin + progesterone sample was achieved by reduction of the albumin content. Also, in this sample, higher concentrations of prealbumin were obvious and two new post-albumin bands appeared. Each was approximately $4-5 \%$ of the total uterine protein, each was obvious in 2 of the 3 samples tested, and neither was apparent in samples from any other treatment group.

Table 2 illustrates the effects of large amounts of prolactin on uterine secretions and embryos when administered during pregnancy. Uteroglobin concentrations were exceptionally low (typically around $10 \%$ ), the embryo recovery/ovulation site ratio was $43 \%$ lower than in controls and about $25 \%$ of the embryos were abnormal, compared to less than $3 \%$ in the sham-injected controls.

\section{Influence of season on steroid hormone receptor concentrations}

As shown in Fig. 3, there were no seasonally dependent changes in the concentration of cytosolic oestrogen receptor for any of the treatment groups. However, a measurable overlap in the range of 


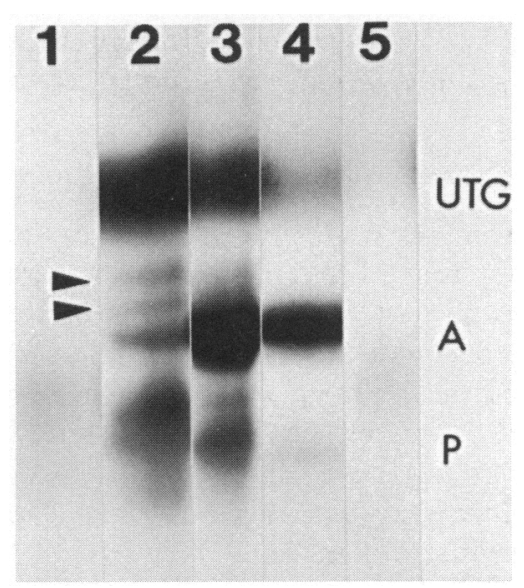

Fig. 2. Electrophoretic profiles of uterine secretions from ovariectomized does treated as follows: lane 1, sham-injected; lanes 2 and 3 , prolactin, $2 \mathrm{mg}$ and $1 \mathrm{mg}$, respectively, plus progesterone $(3 \mathrm{mg} / \mathrm{kg})$; lane 4 , progesterone alone; lane 5 , prolactin $(2 \mathrm{mg} / \mathrm{ml})$ alone. Protein bands are labelled UTG (uteroglobin), A (albumin) and P (prealbumin). Two new secretory proteins, detectable after the administration of $2 \mathrm{mg}$ prolactin $/ \mathrm{ml}+$ progesterone, are indicated at the arrows.

Table 2. Effects of administering $2 \mathrm{mg}$ prolactin/day to early pregnant does

\begin{tabular}{|c|c|c|c|c|c|c|c|}
\hline \multirow{2}{*}{$\begin{array}{l}\text { Rabbit } \\
\text { no. }\end{array}$} & \multirow{2}{*}{$\begin{array}{c}\text { No. of } \\
\text { CL }\end{array}$} & \multirow{2}{*}{$\begin{array}{l}\text { No. of } \\
\text { mature } \\
\text { follicles }\end{array}$} & \multirow{2}{*}{$\begin{array}{l}\text { No. of } \\
\text { embryos } \\
\text { recovered }\end{array}$} & \multicolumn{2}{|c|}{$\begin{array}{c}\text { Condition of } \\
\text { embryos* }\end{array}$} & \multirow{2}{*}{$\begin{array}{l}\% \text { Normal } \\
\text { embryos }\end{array}$} & \multirow{2}{*}{$\begin{array}{l}\text { Uteroglobin } \\
\text { conc. }(\%)\end{array}$} \\
\hline & & & & Normal & Abnormal & & \\
\hline \multicolumn{8}{|c|}{ Treated does } \\
\hline 1 & 16 & 11 & 13 & 9 & 4 & 56 & 12 \\
\hline 2 & 16 & 10 & 9 & 7 & 2 & 43 & 10 \\
\hline 3 & 10 & 4 & 7 & 6 & 1 & 60 & 11 \\
\hline 4 & 15 & 8 & 10 & 7 & 3 & 47 & 4 \\
\hline \multicolumn{8}{|c|}{ Sham-injected does } \\
\hline 5 & 10 & 2 & 9 & 9 & 0 & 90 & 48 \\
\hline 6 & 9 & 0 & 9 & 9 & 0 & 100 & 47 \\
\hline 7 & 9 & I & 8 & 8 & 0 & 89 & 60 \\
\hline 8 & 11 & 2 & 10 & 9 & 0 & 82 & $-\dagger$ \\
\hline
\end{tabular}

${ }^{*}$ Normal is when the 5-day-old blastocysts are $0.8-1.2 \mathrm{~mm}$ diameter, of good conformity and having intact membranes; abnormal is when the embryos are small, typically $0.2-0.3 \mathrm{~mm}$ in diameter, collapsed, have disaggregated cells, and/or are clearly necrotic.

†Sample lost.

oestrogen receptor values existed for oestrous (5.6-17.6 pmol/mg DNA) compared to ovariectomized (5.4-11.8 pmol/mg DNA) rabbits, with the greatest approximation of values occurring in the spring. During the winter the concentration of cytosolic oestrogen receptor was $69 \%$ of the value for oestrous control rabbits, increasing to $87 \%$ during the spring. Prolactin treatment of ovariectomized rabbits resulted in an increase in the concentration of cytosolic oestrogen receptor compared to ovariectomized control rabbits in any season of the year. As shown in Fig. 3, the receptor value for prolactin treated ovariectomized rabbits was $125 \%$ of that of oestrous controls in the winter, 
increasing to $161 \%$ in the spring. There were no apparent seasonally dependent changes in the concentration of cytosolic progesterone receptor for any of the treatment groups (Fig. 3). Ovariectomy resulted in a decrease $(P<0.01)$ in the concentration of cytosolic progesterone receptor, and prolactin treatment restored the concentration to oestrous control values in winter and spring. For all other treatment groups, the concentration of cytosolic progesterone receptor was equivalent to the value for ovariectomized rabbits.
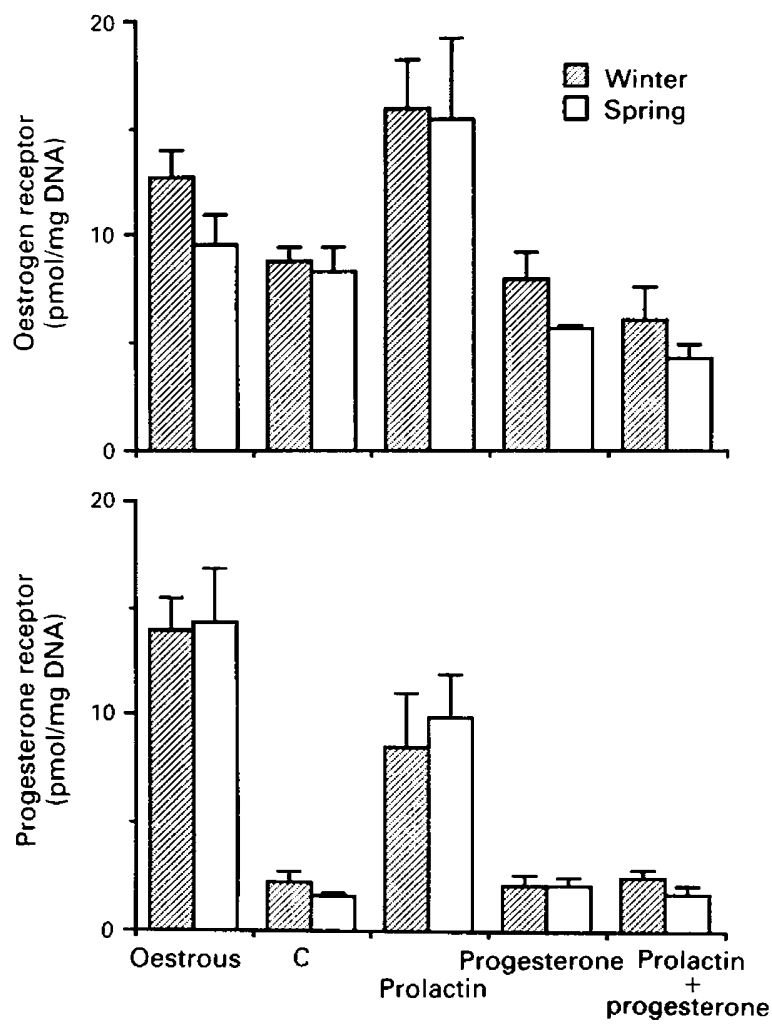

Fig. 3. Comparison of cytosolic oestrogen and progesterone receptor concentrations for all treatment groups during winter and spring. Controls $(\mathrm{C})$ were long-term ovariectomized does. Values are mean \pm s.e.m. for 90 does (3-6/treatment/season).

\section{Discussion}

The most interesting aspect of this study is the demonstration that the changing seasons affect the way the rabbit uterus responds to hormones. Both the mammalian and the avian reproductive tracts are influenced by seasonal cycles, and several examples of circannual rhythms in steroidreceptor binding have been noted in the Introduction. Of particular interest is the recent documentation by Stern \& Vaughan (1987) of a 10-fold, seasonally dependent variation in the affinity of the oestrogen receptor for ligand in the uteri of rabbits from the same Tennessee colony as used in this report. Equilibrium binding constants $\left(K_{\mathrm{a}}\right)$ were lowest in January-February and highest from August through December. Stern \& Vaughan (1987) correlated the increase in the $K_{\mathrm{a}}$ values with an increase in photoperiod, and we have presented evidence that the affinity of the oestrogen receptor for ligand is increased 5-fold by prolactin treatment (Chilton \& Daniel, 1987). 
Oestradiol induces both oestrogen and progesterone receptors (Leavitt et al., 1983) and the concentration of receptor protein is known to be a major factor in regulating cellular sensitivity to steroid hormones (Katzenellenbogen, 1980). However, using adult female rabbits, Batra \& Kallstrand (1979) have demonstrated a decrease $(P<0.05)$ in the serum concentration of oestradiol in September, when Stern \& Vaughan (1987) report that the $K_{\mathrm{a}}$ for oestrogen receptor is increased, and an increase in the serum value of oestradiol in January when the $K_{\mathrm{a}}$ for oestrogen receptor is decreased. It therefore seems possible that the requirement of target cells for oestradiol may be modified by alterations in the kinetic properties of the receptor. The absence of seasonally dependent changes in the concentrations of cytosolic oestrogen and progesterone receptors supports this hypothesis.

Although domestic rabbits are generally thought to be in perpetual oestrus when not pregnant, they do have periods of anoestrus or low reproductive success, usually associated with the coldest part of the winter and the hottest part of the summer. The greatest incidence of reproductive success occurs in the spring, when litter size and number of live births per litter reaches a maximum (Hafez, 1970). The effects of prolactin on the secretory response of the uterine endometrium is greatest in the winter in Tennessee rabbits when reproductive competence in intact females normally reaches a nadir. Conversely, the greatest effect with animals from the New Mexico colony was seen in the spring and the North Carolina animals showed no significant seasonal difference. Clearly, strain differences modulate the seasonal response but other unknown conditions may also be implicated.

In long-term ovariectomized rabbits, the adrenal glands continue to produce sex steroids (Overstrom \& Black, 1980) and endogenous prolactin remains detectable (Chilton \& Daniel, 1987). However, Urbanski \& Ojeda (1986) have shown that, while ovarian-independent discharges of prolactin continue to occur as mid-afternoon surges in long-term ovariectomized rats (i.e. up to 7 weeks), exogenous oestradiol amplifies the magnitude of the surge. Thus, increasing serum concentrations of prolactin may compensate, at the cellular level, for the loss of pulse amplitude.

The production of high concentrations of uteroglobin after treatment of ovariectomized rabbits, from the New Mexico strain, with $2 \mathrm{mg}$ prolactin, followed by progesterone, confirms the involvement of prolactin with uterine secretory activity. This also provides the basis for explaining some of the inconsistencies in response obtained when animals were treated with the lower doses of prolactin which were apparently suboptimal. Although prolactin is generally somatogenic for many target tissues (Friesen et al., 1985; Nicoll et al., 1985), in the rabbit uterus prolactin treatment results in increased concentrations of cytosolic oestrogen and progesterone receptors, while prolactin + progesterone enhances uteroglobin secretion; and growth hormone does not mimic these prolactin-specific actions in the rabbit uterus (Chilton \& Daniel, 1987).

Rabbit uterine secretions are a mixture of serum proteins and locally synthesized proteins, production of which is hormonally regulated. In addition to uteroglobin, other uterine proteins are induced by progesterone (see Beier \& Beier-Hellwig, 1973; Daniel, 1976; Chilton \& Daniel, 1978; Dunbar \& Daniel, 1979; Denker, 1980; Kirchner, 1980) and typically appear in predictable concentrations and at specific times during pregnancy. When the uteroglobin is decreased from $\sim 60 \%$, on the 5 th day of normal pregnancy to $10-11 \%$ by the administration of large amounts of prolactin, the balance between uteroglobin and other uterine proteins is clearly disrupted. The increased loss and abnormality of embryos under these experimental conditions provides additional evidence that specific proteins in the uterine milieu are essential for early embryogenesis or that the low concentrations or imbalanced proportions of uterine proteins are detrimental to preimplantation embryos (Beier, 1974). Conversely, when a high dose of prolactin is given to long-term ovariectomized does, along with progesterone, it raises uteroglobin levels to $60 \%$, reduces the albumin content, increases the prealbumin(s) and apparently induces the production of 2 additional proteins, which migrate as post-albumins, and which were either absent or undetectable following all other treatments. Both experiments provide additional evidence that prolactin influences the composition of uterine proteins in the rabbit. 
The increase in the number of corpora lutea and mature follicles in the ovaries of animals given prolactin in early pregnancy, compared to the sham-injected controls, and the decrease in the proportion of embryos recovered, provides the basis for the suggestion that secondary ovulations may be induced by prolactin. Prolactin is known to have a luteotrophic action (Armstrong et al., 1969; Dorfman, 1972; McNatty et al., 1980; Jayatilak et al., 1985), and to promote the growth of ovarian surface epithelium (Osterholzer et al., 1985), and may play a role in oocyte maturation (Laufer et al., 1984). Additional follicles would be expected to increase production of oestrogens, which, antagonistic to progesterone, could cause the observed reduction in uteroglobin synthesis. However, Hamada et al. (1980) report that prolactin inhibits ovulation. Future studies will seek resolution of this question.

Seasonal, strain and dosage variables influence the effect of prolactin on the response of the rabbit uterus to progesterone as measured by uteroglobin production but fail to influence the effect of prolactin on steroid receptor concentrations. It is expected that other factors, not yet identified, also influence this interaction and that their characterization will help define the mechanism whereby prolactin augments the uterine secretory response to progesterone.

We thank Mr Bill M. Wallace for technical assistance. This work was supported by NIH Grant HD 20271 (J.C.D. \& B.S.C.). B.S.C. is the recipient of NIH RCDA No. HD00704.

\section{References}

Armstrong, D.T., Jackaricz, T.M. \& Keyes, P.L. (1969) Regulation of steroidogenesis in the rabbit ovary. In The Gonads, pp. 3-25. Ed. K. W. McKerns. Appleton Century Crofts, New York.

Barbanel, G. \& Assenmacher, I. (1984) Diurnal variations in estradiol binding site concentrations in the hypothalamus, pituitary and uterus of prepuberal rats. $J$. steroid Biochem. 20, 539-543.

Batra, S. \& Kallstrand, K. (1979) Are there cyclic variations in estradiol secretion in the non-pregnant rabbit? Experientia 35, 699-701.

Beier, H.M. (1974) Oviducal and uterine fluids. $J$. Reprod. Fert. 37, 221-237.

Beier, H.M. \& Beier-Hellwig, K. (1973) Specific secretory protein of the female genital tract. Acta endocr., Copenh., Suppl. 180, 404-425.

Burton, K. (1956) A study of the conditions and mechanisms of the diphenylamine reaction for the colorimetric estimation of deoxyribonucleic acid. Biochem. $J .62,315-323$.

Chilton, B.S. \& Daniel, J.C. (1978) Rabbit endometrial RNA- and DNA-dependent DNA polymerase activity. Biol. Reprod. 18, 371-378.

Chilton, B.S. \& Daniel, J.C. (1985) Influence of prolactin on DNA synthesis and glandular differentiation in rabbit uterine endometrium. Prolactin, Basic and Clinical Correlates 1, 351-359.

Chilton, B.S. \& Daniel, J.C. (1987) Differences in the rabbit uterine response to progesterone as influenced by growth hormone or prolactin. J. Reprod. Fert. 79, 581-587.

Crowle, A.J. (1973) Single diffusion tests. In Immunodiffusion, 2nd edn, pp. 207-245. Academic Press, New York.

Daniel, J.C. (1976) Temporal relationships between six uterine proteins associated with early pregnancy in the rabbit. In Protides of the Biological Fluids, pp. 133-137. Ed. H. Peeters. Pergamon Press, Oxford.
Daniel, J.C. \& Boyce, P.K.W. (1978) Surgical induction of endometriosis. In Methods in Mammalian Reproduction, ch. 25, pp. 545-555. Ed. J. C. Daniel, Jr. Academic Press, New York.

Daniel, J.C., Jetton, A.E. \& Chilton, B.S. (1984) Prolactin as a factor in the uterine response to progesterone in rabbits. J. Reprod. Fert. 72, 443-452.

Denker, H.W. (1980) Endometrial arylamidase secretion: A sensitive parameter of steroid hormone action and of embryo-maternal interrelationships in the rabbit. In Steroid-Induced Uterine Proteins, pp. 121-131. Ed. M. Beato. Elsevier/North-Holland Biomedical Press, Amsterdam.

Dorfman, R.I. (1972) Mechanism of action of gonadotropins and prolactin. In Biochemical Actions of Hormones, vol. 2, pp. 295-316. Ed. G. Litwack. Academic Press, New York.

Dunbar, B.S. \& Daniel, J.C., Jr (1979) High molecular weight components of rabbit uterine fluids. Biol. Reprod. 21, 723-733.

Friesen, H.G., Gertler, A., Walker, A. \& Elsholtz, H. (1985) Mechanism of action of prolactin in stimulating cell growth. Prolactin, Basic and Clinical Correlates 1, 315-326.

Furlong, C.E., Cirakoglu, C., Willis, R.C. \& Santy, P.A. (1973) A simple preparative polyacrylamide disc gel electrophoresis apparatus: purification of three branched-chain amino acid binding proteins from Escherichia coli. Analyt. Biochem. 51, 297-311.

Hafez, E.S.E. (1970) Rabbits. In Reproduction and Breeding Techniques for Laboratory Animals, pp. 273298. Ed. E. S. E. Hafez. Lea and Febiger, Philadelphia.

Hamada, Y., Schlaff, S., Kobayashi, Y., Santulli, R., Wright, K.H. \& Wallach, E.E. (1980) Inhibitory effect of prolactin on ovulation in the in vitro perfused rabbit ovary. Nature, Lond. 285, 161-163.

Hughes, A., Jacobson, H.I., Wagner, R.K. \& Jungblut, P.W. (1976) Ovarian-independent fluctuations of 
estradiol receptor levels in mammalian tissues. Molec. cell. Endocr. 5, 379-388.

Jayatilak, P.G., Glaser, L.A., Basuray, R., Kelly, P.A. \& Gibori, G. (1985) Identification and partial characterization of a prolactin-like hormone produced by rat decidual tissue. Proc. natn. Acad. Sci. U.S.A. 82, 217-221.

Katzenellenbogen, B.S. (1980) Dynamics of steroid hormone receptor action. Annu. Rev. Physiol. 42, 17-35.

Kirchner, C. (1980) Non-uteroglobin proteins in the rabbit. In Steroid-Induced Uterine Proteins, pp. 69 85. Ed. M. Beato. Elsevier/North Holland Biomedical Press, Amsterdam.

Laufer, N., Botero-Ruiz, W., Decherney, A.H., Haseltine, F., Polan, M.L. \& Behrman, H.R. (1984) Gonadotropin and prolactin levels in follicular fluid of human ova successfully fertilized in vitro. J. clin. Endocr. Metab. 58, $430-434$.

Leavitt, W.W., MacDonald, R.G. \& Okulicz, W.C. (1983) Hormonal regulation of estrogen and progesterone receptor systems. In Biochemical Actions of Hormones, vol. 10, pp. 323-356. Ed. G. Litwack. Academic Press, New York.

Lowry, O.H., Rosebrough, N.J., Farr, A.L. \& Randall, R.J. (1951) Protein measurement with the folin phenol reagent. J. biol. Chem. 193, 265-275.

MeNatty, K.P., Makris, A., Osathanondh, R. \& Ryan, K.J. (1980) Effects of luteinizing hormone on steroidogenesis by thecal tissue from human ovarian follicles in vitro. Steroids 36, 53-63.

Nicoll, C.S., Anderson, T.R., Herbert, N.J. \& Russell, S.M. (1985) Comparative aspects of the growthpromoting actions of prolactin on its target organs: evidence for synergism with an insulin-like growth factor. Prolactin, Basic and Clinical Correlates 1, $393-410$.

Osterholzer, H.O., Streibel, E.J. \& Nicosia, S.V. (1985) Growth effects of protein hormones on cultured rabbit ovarian surface epithelial cells. Biol. Reprod. 33, 247-258.

Oudin, J. (1952) Specific precipitation in gels and its application to immunochemical analysis. In Methods in Medical Research, vol. 4, pp. 335-378. Ed. A. C. Corcoran. Year Book Publishers, Chicago.

Overstrom, E.W. \& Black, D.L. (1980) Effect of ovariectomy and adrenalectomy on peripheral plasma concentration of estradiol and progesterone in the rabbit. Biol. Reprod. 22, 134, Abstr.

Scatchard, G. (1949) The attractions of proteins for small molecules and ions. Ann. N.Y. Acad. Sci. 51, $660-672$.

Spelsberg, T.C., Littlefield, B.A., Seelke, R., Dani, G.M., Toyoda, H., Boyd-Leinen, P., Thrall, C. \& Kon, O.L. (I983) Role of specific chromosomal proteins and DNA sequences in the nuclear binding sites for steroid receptors. Recent Prog. Horm. Res. 39, 463-517.

Stern, J.E. \& Vaughan, G.L. (1987) Seasonal changes in oestrogen receptor affinity in the domestic rabbit, Oryctolagus cuniculus. J. Reprod. Fert. 79, 15-20.

Urbanski, H.F. \& Ojeda, S.R. (1986) Development and amplification of mid-afternoon surges of prolactin secretion in ovariectomized immature rats. J. Endocr. $110,361-366$.

Received 29 September 1987 